\title{
Global overview of refugees: comparison of 2005 and 2015 data for the 10 most affected countries
}

Rana Cavusoglu, ${ }^{1}$ Gamze Aktuna, ${ }^{1}$ Ekin Koc, ${ }^{2}$ Dilek Aslan ${ }^{3}$ and Marwa Osman ${ }^{1}$

${ }^{1}$ Institute of Health Sciences, Department of Public Health, Hacettepe University, Ankara, Turkey. ${ }^{2}$ Konya Public Health Presidency, Konya, Turkey. 32Department of Public Health, Faculty of Medicine, Hacettepe University, Ankara, Turkey (Correspondence to: Rana Cavusoglu: rana9.cavusoglu@ gmail.com).

\begin{abstract}
Background: The refugee problem has become a global concern with multidimensional characteristics. Monitoring migration flows over time and comparing the situation with a number of indicators can give clues on how to manage the problem.

Aims: In this study, the global refugee issue was discussed by focusing on such data including the potential factors causing crises in the most affected countries.

Methods: In this ecological study, the analysis was completed for the countries that either "host" or "source" refugees between 2005 and 2015. Excel-dataset was formed for United Nations Development Programme (UNDP), World Bank and United Nations High Commissioner for Refugees (UNHCR) datasets and were converted to SPSS-23.0. Mapping was done via pixelmap.

Results: In 2005, Pakistan, Islamic Republic of Iran, and the United States of America were the first three on the hosting country list, while Germany ranked 8th and China 9th. In 2015, Turkey ranked first as hosting country while previously it was not even in the top 10 countries. Geographical proximity plays a crucial role during displacement. Countries differ from each other according to the values of selected indices.

Conclusions: Global solutions integrated with local precautions to reduce the worldwide burden of migration are required.

Keywords: refugees, global migration, civil war, health determinants, public health

Citation: Cavusoglu R; Aktuna G; Koc E; Aslan D; Osman M. Global overview of refugees: comparison of 2005 and 2015 data for the 10 most affected countries. East Mediterr Health J. 2019;25(6):435-440. https://doi.org/10.26719/emhj.18.050

Received: 20/10/17; accepted: 26/07/18

Copyright (C) World Health Organization (WHO) 2019. Some rights reserved. This work is available under the CC BY-NC-SA 3.o IGO license (https:// creativecommons.org/licenses/by-nc-sa/3.o/igo).
\end{abstract}

\section{Introduction}

Immigration is considered as old as the history of Mankind. Societies or communities in the Ancient World have been recorded performing migrations from one region to another for the sake of a better environment and livelihood. Migration has a broad impact, and today it is estimated that 22.5 million (1) people around the world have been affected by migratory pressures and are considered as "vulnerable" populations (2).

Numerous aspects of migration in the 21st century have been addressed by scholars in various disciplines such as anthropology, public health, and sociology. Public health as an interdisciplinary study also focuses on this issue by examining the mental, social and physical wellbeing of refugees. The current refugee problem is a hotly debated topic globally due to the considerable number of people (millions in number) moving from one place to another every second worldwide, resulting in various migratory pressures and problems (3).

A number of scientific papers and reports, primarily from the European Union and the United Nations, have pointed out the effect of globalization, economic crises, conflicts, wars, etc. as the factors contributing to the refugee crises (4-8). Every country has its own approach to handling the presence of refugees within its borders, and the literature emphasizes the importance of evidence-based policies to deal with refugees with regard to health risks and burden on health systems, and the importance of building inclusive cost-effective health services. In addition, it is important to acknowledge that conflicts, health and socioeconomic inequalities between high-income and low- and middle-income countries are major causes of the current refugee crisis, which need to be addressed when seeking long-term solutions (9).

As the scientific data/evidence accumulates, it will become clearer how to enact effective solutions; thus, it is crucial to assess the refugee situation at the global level in order to contribute to the literature on migration for health service planning following an interdisciplinary approach. Therefore, this article aimed to define the global refugee issue by focusing on the potential factors causing crises in severely affected countries.

\section{Methods}

This ecological study focuses on general disease trends seen as prevalent by analysing the global data between 2005 and 2015, on countries which either hosted or gave refugees. An original excel dataset was formed by gather- 
ing UNDP World Bank and UNHCR open access datasets $(10-12)$. The excel format was turned to SPSS 23.0, and data analysis was done by using this set. Mapping was done via pixelmap (13).

Number of refugees, Human Development Index (HDI), potential/possible reasons for refugee movement, gender-related indicators (female \% and Gender Inequality Index [GII]), the status of the country (either hosting or source of refugees) were used as variables. The study was subject to the limitations of an ecological study. No ethical permission was required as the datasets are available to the public.

$\begin{aligned} & \text { Table 1: Top } 10 \text { refugee/asylum seeker hosting countries (2005 } \\
& \text { and 2015) }\end{aligned}$
\begin{tabular}{ll}
\multicolumn{1}{c}{2005} & \multicolumn{1}{c}{2015} \\
1. Pakistan & 1. Turkey* \\
2. Islamic Republic of Iran & 2. Pakistan \\
3. United States of America* & 3. Lebanon* \\
4. Uganda & 4. Islamic Republic of Iran \\
5. Chad & 5. Ethiopia \\
6. Kenya & 6. Jordan * \\
7. Democratic Republic of & 7. Kenya \\
Congo & 8. Uganda \\
8. Germany* & 9. Democratic Republic of \\
9. China* & Congo \\
10. Ethiopia &
\end{tabular}

\section{Results}

The top 10 refugee/asylum seeker-hosting countries between 2005 and 2015 are listed in Table 1. In 2005, Pakistan, Islamic Republic of Iran and the United States of America were the top three countries on the list, while Germany ranked eighth and China ninth. In 2015, Turkey ranked first as hosting country while previously it was not even in the top 10 countries.

Table 2 lists the top 10 countries that were the source for refugees/asylum seekers between 2005 and 2015. In 2005 Afghanistan, Sudan and Iraq were the top three countries on the list. The Syrian Arab Republic is the

$\begin{aligned} & \text { Table 2: Top ten "source" countries for refugees/asylum seekers } \\ & \text { (2005 and 2015) }\end{aligned}$
Source countries of the refugees
2005

Figure 1: Major "hosting" and "source" countries for refugees/asylum seekers (2005)

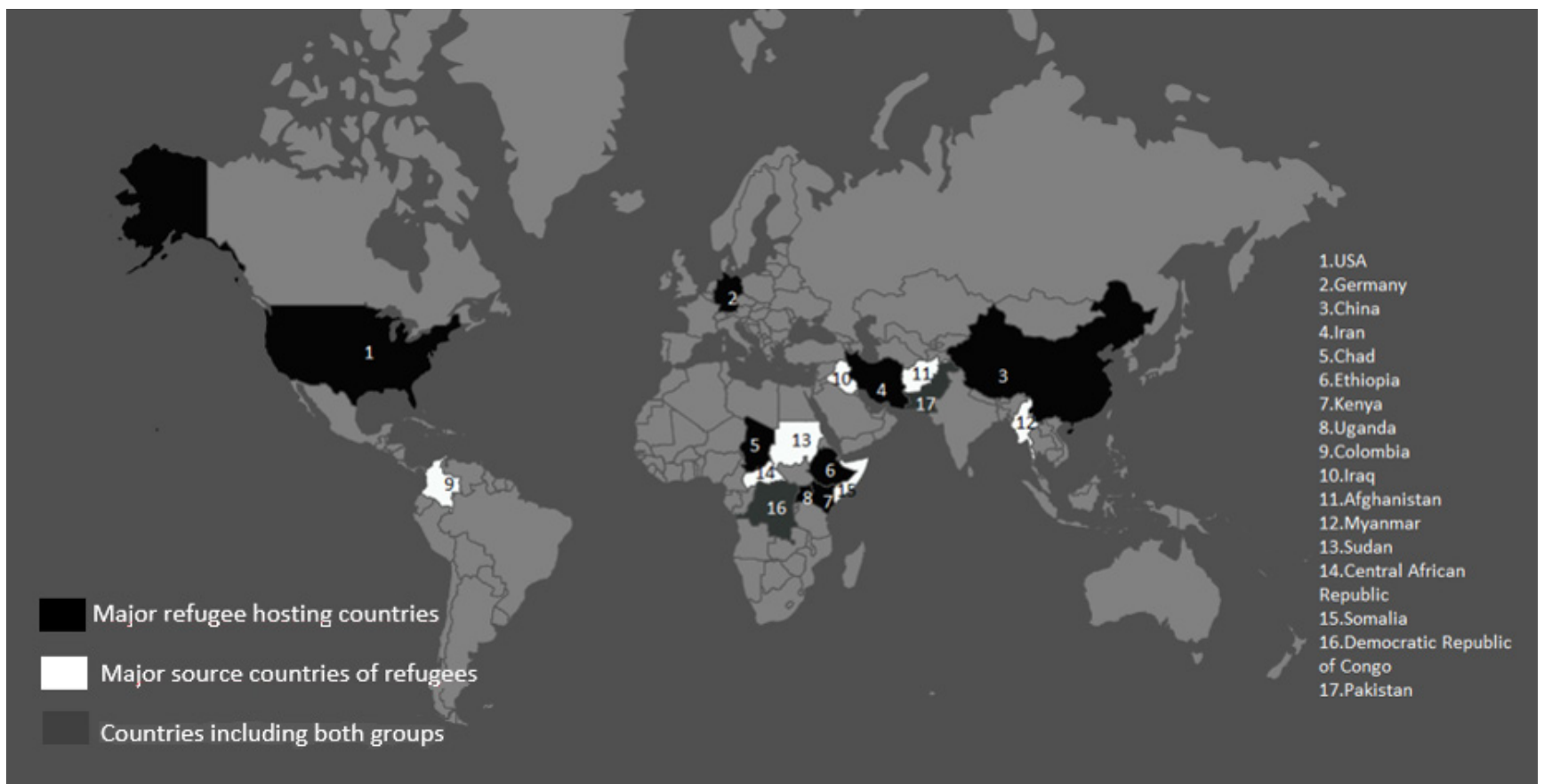


major "source" country in 2015, followed by Afghanistan and Somalia.

The global picture of the geographical movement of refugees is indicated in Figure 1 and Figure 2. The major shift is from lower-income regions of the world to "relatively" high-income destinations. Border countries remain an important determinant for migratory paths.

Table 3 and Figure 3 show major "hosting" countries and source of refugees/asylum seekers. Geographical proximity plays a crucial role in displacement movements.

Hosting countries' HDI values are higher than in source countries, although HDI values and Gender Inequality Index values vary between hosting countries (Table 4).

\section{Discussion}

This article briefly draws a global picture of the refugee situation for those countries affected since 2005. Migrations from low- and middle-income regions to relatively high-income destinations were instigated by factors such as regional war, conflict, hunger, etc. (14). In 2015, Turkey ranked first as hosting country in 2015 while previously it was not even in the top 10 countries (Table 1). The Syrian Arab Republic is significant as being the major source country for refugees/asylum seekers in 2015 (Table 2) due to the civil war which has been ongoing since $2011(15,16)$.

In our study, we found that refugees flee primarily to neighbouring countries to seek immediate safety from the ongoing life-threatening situation in their home countries. In addition, cultural and other common ties

Figure 2: Major "hosting" and "source" countries of refugees/asylum seekers (2015)

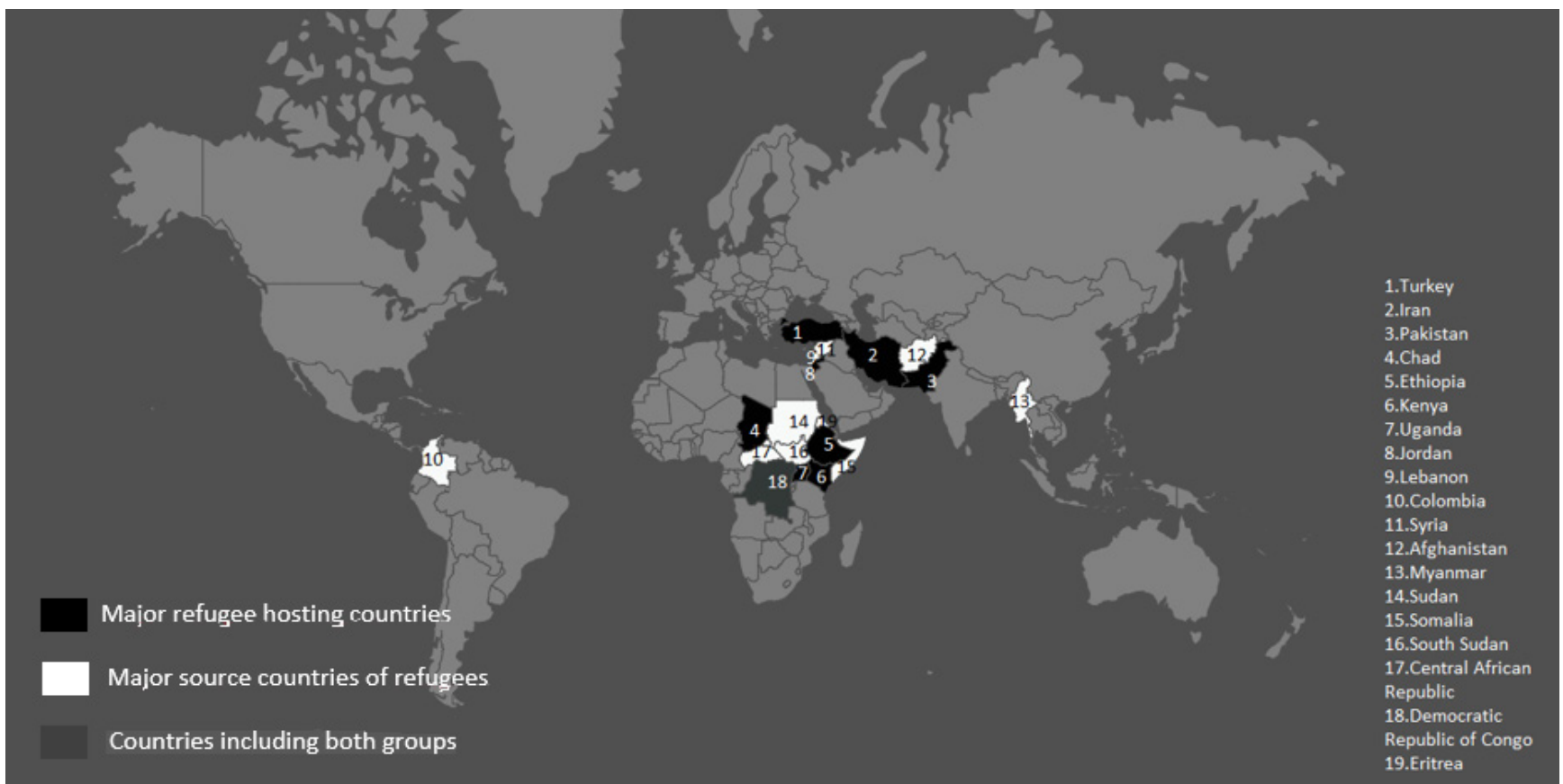

\begin{tabular}{|c|c|}
\hline Hosting country & $\begin{array}{l}\text { Country of refugee/ } \\
\text { asylum seeker origin }\end{array}$ \\
\hline 1. Turkey & 1. Syrian Arab Republic \\
\hline 2. Pakistan & 2. Afghanistan \\
\hline 3. Lebanon & 3. Syrian Arab Republic \\
\hline 4. Islamic Republic of Iran & 4. Afghanistan \\
\hline 5. Ethiopia & 5. South Sudan \\
\hline 6. Jordan & 6. Syrian Arab Republic \\
\hline 7. Kenya & 7. Somalia \\
\hline 8. Uganda & $\begin{array}{l}\text { 8. Democratic Republic of } \\
\text { Congo }\end{array}$ \\
\hline 9. Democratic Republic of Congo & 9. Rwanda \\
\hline 10. Chad & 10. Sudan \\
\hline
\end{tabular}

${ }^{*}$ Country removed and/or added to the list

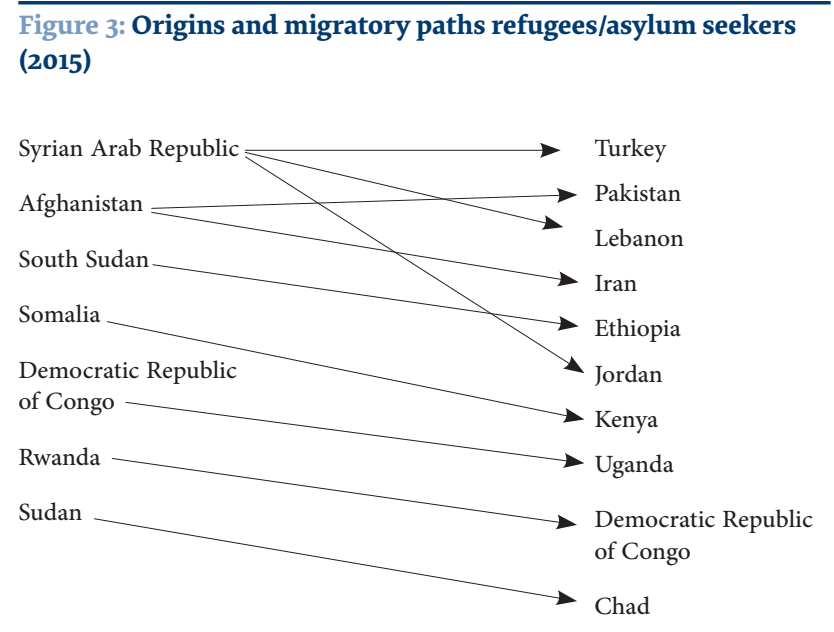

Figure 3: Origins and migratory paths refugees/asylum seekers 


\begin{tabular}{|c|c|c|c|c|}
\hline \multirow[t]{3}{*}{ Country } & \multicolumn{4}{|c|}{ Host/source of refugees } \\
\hline & \multirow{2}{*}{$\begin{array}{l}\text { Human Development } \\
\text { Index }\end{array}$} & \multirow[t]{2}{*}{ Gender indicators } & \multicolumn{2}{|c|}{ Gender indicators } \\
\hline & & & Female \% & $\begin{array}{c}\text { Gender Inequality } \\
\text { Index }\end{array}$ \\
\hline Turkey & $\mathrm{H}$ & 0.764 & 49.2 & 0.908 \\
\hline Pakistan & $\mathrm{H}$ & 0.550 & 48.6 & 0.741 \\
\hline Lebanon & $\mathrm{H}$ & 0.763 & 49.7 & 0.893 \\
\hline Islamic Republic of Iran & $\mathrm{H}$ & 0.774 & 49.6 & 0.862 \\
\hline Ethiopia & $\mathrm{H}$ & 0.448 & 50.0 & 0.842 \\
\hline Jordan & $\mathrm{H}$ & 0.742 & 48.7 & 0.864 \\
\hline Kenya & $\mathrm{H}$ & 0.560 & 50.0 & 0.919 \\
\hline Uganda & $\mathrm{H}$ & 0.493 & 50.0 & 0.873 \\
\hline $\begin{array}{l}\text { Democratic Republic of } \\
\text { Congo }\end{array}$ & $\mathrm{H}$ & 0.435 & 50.1 & 0.932 \\
\hline Chad & $\mathrm{H}$ & 0.396 & 49.9 & 0.765 \\
\hline Syrian Arab Republic & S & 0.536 & 49.3 & 0.850 \\
\hline Afghanistan & S & 0.479 & 48.4 & 0.609 \\
\hline Somalia & S & - & 50.2 & 0.838 \\
\hline South Sudan & S & 0.418 & 49.9 & NA \\
\hline Sudan & S & 0.490 & 49.8 & $0.628^{*}$ \\
\hline $\begin{array}{l}\text { Democratic Republic of } \\
\text { Congo }\end{array}$ & $S$ & 0.560 & 50.0 & 0.919 \\
\hline Central African Republic & S & 0.352 & 50.7 & 0.776 \\
\hline Myanmar & S & 0.556 & 51.1 & $0.459^{* *}$ \\
\hline Eritrea** $^{* *}$ & S & 0.410 & 50.0 & - \\
\hline Colombia & S & 0.727 & 50.7 & 0.993 \\
\hline
\end{tabular}

could be other strong motivational factors for fleeing to neighboring countries, as well presence of international agreements between countries that stipulate the displacement of civilians to humanitarian camps nearby.

Displaced people may consider middle and highincome countries as a future destination after securing their own safety first (14). Germany and the United States of America were not on the host country list until 2014.

Although we performed comparisons between refugee hosting and/or source countries using HDI and GII values, drawing conclusions may be premature with such limited data. Although host countries generally tend to have better HDIs than source countries, in some cases such indicators between the host and the source countries are in fact similar. This could be due to the fact that refugees select the nearest geographical safe countries rather than considering the degree of development.

\section{Limitations}

Since this is an ecological study, the analyses were conducted on communities and/or groups instead of individuals. Personal experiences and their effects due to displacement could not be fully addressed. Data were obtained from more than one source; this caused particular difficulty in adapting into the same data base. Only open access indicators could be discussed.

\section{Conclusion}

Considering the complex nature of the causes of migration, it is necessary to adopt a multi/inter-disciplinary approach to reduce/eliminate the adverse effects of migration on public health. More detailed data sets, including various indicators, will help to assist in finding solutions.

Funding: None.

Competing interests: None declared. 


\section{Aperçu mondial sur la situation des réfugiés : comparaison des données de 2005 et 2015 pour les dix pays les plus touchés}

\section{Résumé}

Contexte : Le problème des réfugiés est devenu une préoccupation mondiale aux caractéristiques multidimensionnelles. Le suivi des flux migratoires dans le temps et la comparaison de la situation avec un certain nombre d'indicateurs peuvent donner des indices sur la manière de gérer le problème.

Objectifs : Dans la présente étude, la question mondiale des réfugiés a été examinée en se concentrant sur ces données, y compris les facteurs potentiels à l'origine des crises dans les pays les plus touchés.

Méthodes : Dans cette étude holistique, l'analyse a été complétée pour les pays qui «accueillaient » des réfugiés ou « étaient source » de réfugiés entre 2005 et 2015. Un fichier Excel a été créé pour les jeux de données du Programme des Nations Unies pour le développement (PNUD), de la Banque mondiale et du Haut-Commissariat des Nations Unies pour les réfugiés (HCR) et a été converti au format SPSS-23.0. La cartographie a été réalisée via pixelmap.

Résultats : En 2005, le Pakistan, la République islamique d'Iran et les États-Unis d'Amérique étaient les trois premiers sur la liste des pays hôtes, tandis que l'Allemagne et la Chine venaient en huitième et neuvième positions respectivement. En 2015, la Turquie occupait le premier rang en tant que pays hôte, alors qu'elle ne figurait même pas parmi les 10 premiers pays auparavant. La proximité géographique joue un rôle crucial lors des déplacements. Les pays diffèrent les uns des autres en fonctions des valeurs des indices sélectionnés.

Conclusions : Des solutions mondiales intégrées comprenant des précautions locales pour réduire le fardeau mondial des migrations sont nécessaires.

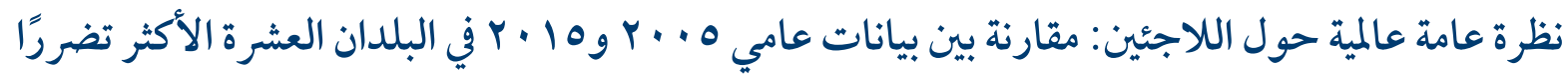

$$
\begin{aligned}
& \text { رنا كافوزوجلو، غمزة أكتونا، إكين كوتش، ديلك أصلان، مروة عثمان } \\
& \text { الخلاصة }
\end{aligned}
$$

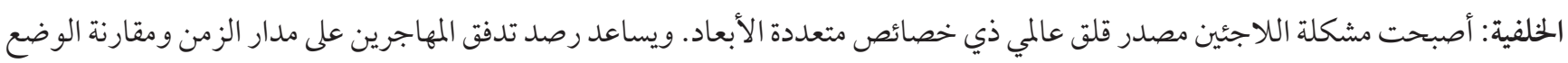

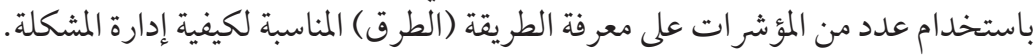

$$
\begin{aligned}
& \text { الأهداف: تمت مناقشة مشكلة اللاجئين العالمية في هذه الدر اسة من خلال التركئ كيز على هذه البيانات، بها في ذلك العو امل المحتملة الـمُسببة للأزمات } \\
& \text { في البلدان الأكثر تضررًا. }
\end{aligned}
$$

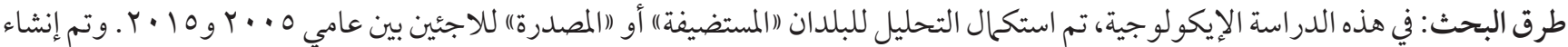

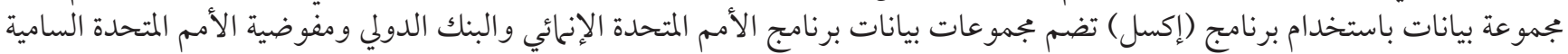

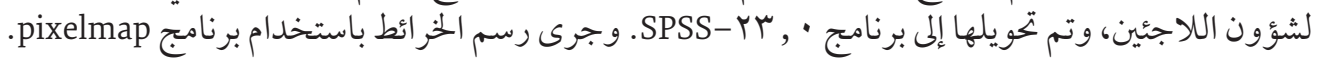

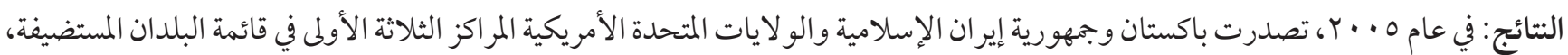

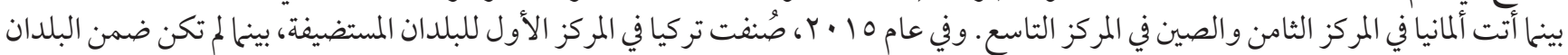

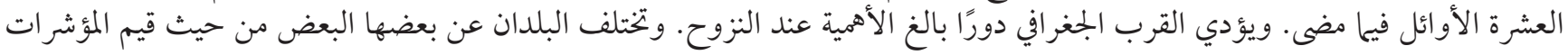

$$
\begin{aligned}
& \text { المحددة. } \\
& \text { الاستنتاجات: يجب وضع حلول عالمية و إدماجها في التدابير الاحتياطية المحلية بهدف تخفيض العبء العالمي من المهاجرين. }
\end{aligned}
$$

\section{References}

1. UNHCR (http://www.unhcr.org/5943e8a34.pdf):2.

2. Humanitarian Practice Network, Special Feature Refugees and Vulnerable Migrants in Europe, Number 67, September 2016 (https://odihpn.org/wp-content/uploads/2016/og/HE-67-FINAL.pdf p 5, accessed 13 May, 2018).

3. UNHCR. Refugees (http://www.unhcr.org/refugees.htm, accessed 13 May, 2018).

4. Health of Resettled Iraqi Refugees San Diego County, California, October 2007- September 2009, Morbidity Weekly Report (https://www.cdc.gov/mmwr/preview/mmwrhtml/mm5949a2.htm, retrieved 13 May, 2018).

5. Bogic M, Njoku A, Priebe S. Long-term mental health of war-refugees: a systematic literature review. BMC Int Health Hum Rights. 2015 Oct 28;15:29.

6. Moore W, Shellman S. Whither will they go? A global study of refugees' destinations, 1965-1995. International Studies Quarterly (2007) 51:811-834. 
7. World Health Organization. Global Health Observatory (GHO) data. Geneva: World Health Organization; 2018 (http://www.who. int/gho/en/, accessed 13 May, 2018).

8. Norredam M, Mygand A, Kransik A. Access to health care for asylum seekers in the European Union - a comparative study of country policies. Eur J Public Health. 2006 Jun;16(3):286-90. https://doi.org/10.1093/eurpub/cki191 PMID: 16230318.

9. Khan MS, Osei-Kofi A, Omar A, Kirkbride H, Kessel A, Abbara A, et al. Pathogens, prejudice, and politics: the role of the global health community in the European refugee crisis. Lancet Infect Dis. 2016 Aug;16(8):e173-7. https://doi.org/10.1016/S14733099(16)30134-7 PMID: 27339456.

10. UNDP. Human Development Reports (http://hdr.undp.org/en/data, accessed 13 May, 2018).

11. The World Bank. Data (http://data.worldbank.org/, accessed 13 May, 2018).

12. UNHCR. Population statistics (http://popstats.unhcr.org/en/persons_of_concern accessed 13 May, 2018).

13. AM Charts. Pixel Map Generator (https://pixelmap.amcharts.com/ accessed 13 May, 2018).

14. Stewart F. Root causes of violent conflict in developing countries. BMJ 2002;324:342. https://doi.org/10.1136/bmj.324.7333.342.

15. Sharara SL, Kanj SS. War and Infectious Diseases: Challenges of the Syrian Civil War. Heitman J, ed. PLoS Pathogens. 2014;10(11):e1004438.

16. Leaning J, Guha-Sapir D. (2013). Natural Disasters, Armed Conflict, and Public Health. N Engl J Med. 2013 Nov 7;369(19):1836-42. https://doi.org/10.1056/NEJMra1109877 PMID: 24195550. 